\title{
The Impact of IT-Business Alignment on SME Performance: The Mediating Effects of Strategic Collaboration, Coordination, and Responsiveness
}

\author{
Rui Bi \\ Charles Sturt University, School of Management and Marketing, Australia \\ rbi@csu.edu.au \\ DOI: 10.34190/EJISE.20.23.1.008
}

\begin{abstract}
The alignment between information technology (IT) and business strategy is regarded as an ongoing issue for information systems (IS) researchers and practitioners. Although prior studies suggest the enabling role of IT-business alignment on firm performance, our understanding of the processes through which such gains are achieved in the small-tomedium enterprise (SME) context still remains unclear. Moreover, there is limited research exporing how SMEs employ the alignment between IT and business strategy to work closely with their business partners in order to achieve business competences. In order to address these research gaps, this study investigates whether and how IT-business alignment enables SMEs to achieve performance goals through developing strategic business activities effectively and efficiently. Using structural equation modelling analyses of survey responses collected from 211 Australian high growth SMEs, we find positive, significant, and impactful linkages between IT-business alignment, strategic collaboration, coordination, responsiveness, and SME performance. The results also show that strategic collaboration, coordination, and responsiveness fully mediate the relationship between IT-business alignment and SME performance. This study contributes to the IS research by providing empirically-supported explanations for the critical role of IT-business alignment in SME success. More significantly, through investigating the effect of IT-business alignment at the inter-mediate business process level, this research provides new insights to understand the underlying influential mechanisms of IT-business alignment in the SME context. These findings have important implications for SME business managers.
\end{abstract}

Keywords: IT-business Alignment, Strategic Collaboration, Coordination, Responsiveness, SME Performance

\section{Introduction}

IT-business alignment refers to the degree to which IT priorities, goals, and objectives are aligned with business plans (Chan and Reich 2007; Sabherwal and Chan 2001). Research highlights that IT-business alignment plays an imperative role in implementing strategic plans and improving business performance in the areas of market growth, financial performance, innovation, reputation, and cost control (Chan et al. 2006; Coltman et al. 2015; Luftman et al. 2015; Sardana et al. 2016; Tallon and Pinsonneault 2011). Although these studies have shown a positive association between IT-business alignment and performance, our understanding of the processes through which such gains can be realized in the small-to-medium enterprise (SME) context still remains limited. SMEs are the driving engines of most economies, creating wealth, income, and jobs (Koryak et al. 2015; Lechner and Gudmundsson 2014). Investigating how SMEs gain real benefit and value from aligning IT with business strategy will have significant implications for the ways in which SMEs approach IT investment and management.

As hyper-competitive environments change the ways firms do businesses with the focus switching from individual organizations to business networks, IT provides new opportunities for companies to conduct business activities with their partners (Bharadwaj et al. 2013; Cui and Pan 2015; Tallon and Pinsonneault 2011). Studies suggest that firms engaging in developing and managing strategic relationships with their business partners can achieve competitive advantage through accessing external skills, resources and knowledge, and responding to external environment changes effectively (Shin et al. 2015; Tan et al. 2014; Theyel 2013). However, limited research has been conducted to expore how SMEs employ the alignment between IT and business strategy to work closely with their business partners in order to achieve business competences. Examining how IT-business alignment affects SMEs to use IT in order to develop business advantages could shed new light on understanding the underlying influential mechanisms on IT business value creation in the SME context.

In order to address the above research gaps, we explore the effectiveness of IT-business alignment on SME performance through the development of business competences, namely, strategic collaboration, coordination, and responsiveness. We empirically examine the hypothesized relationships as shown in Figure 1 with data 
drawn from a survey of 211 Australian high growth SMEs. The contributions of this study are twofold. First, this study provides a rich understanding of how IT strategy has become an integral and tightly woven part of business strategy within innovative and growth-oriented SMEs, enabling them to achieve business value. Second, given that SMEs face an operational paradox of limited resources, but face expanding competition, this study highlights the imperative for SMEs to develop strategic relationships with business partners in order to create and sustain business value in dynamic environments.

Figure 1: Research Model

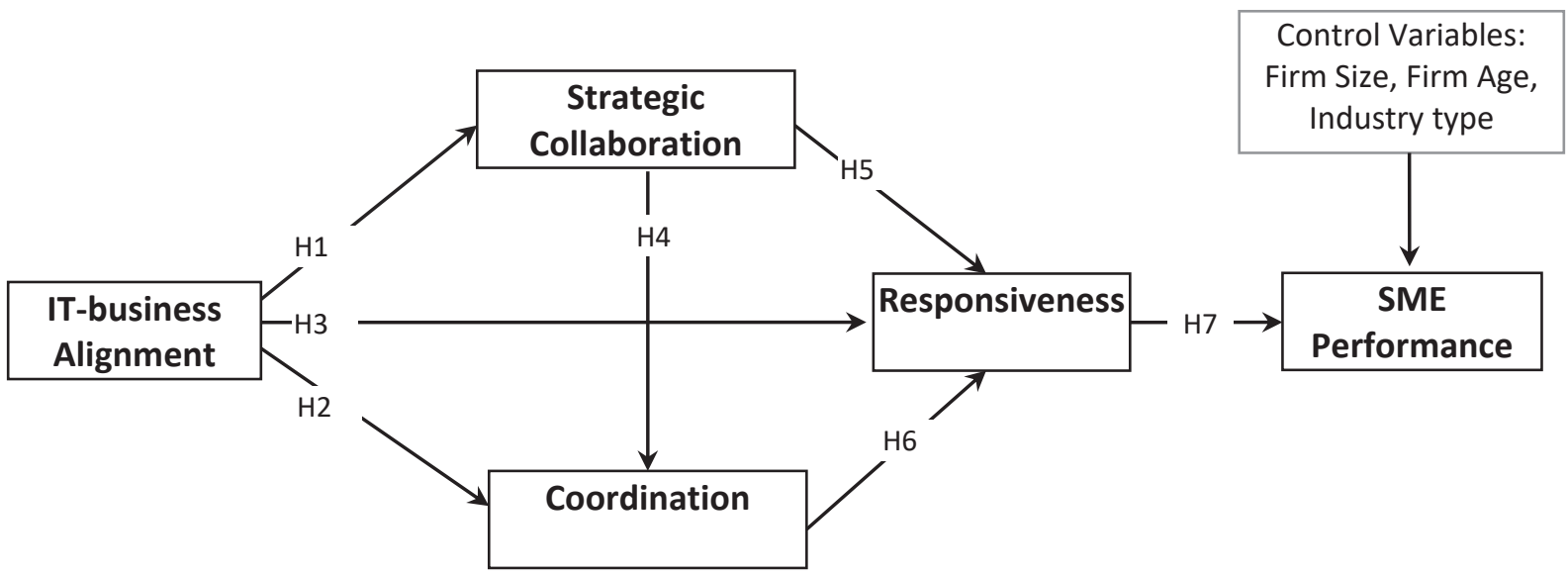

\section{Literature Review and Hypothesis Development}

The potential for a firm to use IT to achieve a competitive position highlights the importance of alignment between IT strategy and business strategy (Coltman et al. 2015; Luftman et al. 2015; Sabherwal et al. 2019). Such alignment not only facilitates acquisition and deployment of IT which is congruent with a firm's competitive needs and strategic objectives (Chang et al. 2008), but also enables companies to effectively capitalize on IT investments to achieve business value (Chan et al. 1997; Sabherwal et al. 2001). The IT-business strategy linkage strengthens the stature of IT within organizations, promoting the financial and managerial support necessary to effectively implement innovative systems (Chen et al. 2010; Cui et al. 2015). Because IT-business alignment plays a prominent role in IT success and competitive advantage, it has become a key concern for top management (Aslesen and Harirchi 2015; Cataldo et al. 2012; Luftman et al. 2015; Ping-Ju Wu et al. 2015).

A growing body of evidence suggests that IT-business alignment plays a central role in SME success (Cragg et al. 2011; Cui et al. 2015). For example, Oh and Pinsonneault (2007) find that aligning IT investment in growthorientated applications with business strategy is necessary for SMEs to gain strategic value. Raymond et al. (2019) comment that SMEs with the ability to integrate IT strategy with business plans can achieve substantive benefits. Du and Temouri (2015) highlight that the reason why SMEs gain business value from IT is because they employ strategic IT planning for their future. Research suggests that top managers play a prominent role in integrating future-oriented IT planning into strategic planning processes in order to achieve substantive benefits (Bergeron et al. 2020; Chao and Chandra 2012). The quality managerial skills of SME managers not only effectively adjust IT plans in accordance with changes in business strategy but also enable firms to seek out, find, and recognize strategic opportunities (Cragg et al. 2013). Findings from these investigations imply that aligning IT strategy with business objectives can be regarded as a crucial determinant of SME performance.

The important business activities between a firm and its business partners involve collecting, interpreting, storing, sharing data, and responding to market changes through effective collaboration and coordination (Whitten et al. 2012). Strategic collaboration is defined as the extent to which a firm collaborates on strategic planning and forecasting activities with its business partners/suppliers (Flynn et al. 2010; Kim and Lee 2010). It reflects a firm's ability to conduct continuous and consistent transactions with its trading partners (Liu et al. 2015; Zhang et al. 2016). Coordination refers to transaction related activities between firm and its business partners (Huo et al. 2015). It reflects the extent to which firms exchange decision rights, knowledge, and resources with each other to streamline business processes (Dong and Yang 2015). Effective coordination involves business activities across partners ranging from collecting and following up orders, identifying customer 
needs, and pursuing new customers (Sahin and Robinson 2005). Responsiveness is a firm-wide capability involving rapid and innovative responses that mitigate risk and exploit growth opportunities in the context of dynamic and uncertain business environments (Lu and Ramamurthy 2011; Sardana et al. 2016). Responsiveness reflects a growth-oriented entrepreneurial mindset involving strategic intent and direction, decision making, judgement, and seamless translation of innovative ideas (Teece et al. 2016; Teece 2012).

Extant research suggests that conducting collaborative and strategic activities are important to SMEs for the following reasons. First, strategic collaboration and coordination enables SMEs to align interests with each other, cultivate trust and commitment, and thus promotes learning and knowledge development within and across companies (Arend 2006; Cenamor et al. 2019; Engel et al. 2017). Second, SMEs with the ability to develop strategic plans together with their business partners can clearly understand and efficiently enact their roles (Chen et al. 2018; Voss and Brettel 2014). Third, collaboration in strategic planning motivates business partners to focus more on achieving long-term common goals rather than individual short-term opportunities (Brouthers et al. 2015; Jespersen et al. 2018). Fourth, strategic collaboration and coordination help SMEs to exchange knowledge and resources, make strategic decisions with their partners effectively and efficiently, and thus increase responsiveness to meet customer demands and seek opportunities to automatically execute tasks in dynamic and turbulent business environments (Bordonaba-Juste and Cambra-Fierro 2009; Corral de Zubielqui et al. 2019; Liao et al. 2003). Although reserach suggests there is positive relationship between IT-busienss alignment and SME performance, added empirical evidence is need to investigate how IT-business alignment enables SMEs to achieve strategic benefits through working closely with their business partners.

IT-business alignment championed by top managers promotes the synchronization of IT and business strategy (Coltman et al. 2015; Ping-Ju Wu et al. 2015; Preston and Karahanna 2009). The synergy between IT and business strategy increases socialization and reduces the adverse effects of differences in norms, cultures and work processes (Tallon and Pinsonneault 2011). The close and active interactions between IT and business lead to sharing and exchange of knowledge (Preston and Karahanna 2009). Such shared knowledge plays an important role in influencing a SME's IT-business alignment (Hussin et al. 2002), strategic IT use (Raymond and Bergeron 2008), and effective IT-business joint decision making (Cragg et al. 2011). IT-business alignment provides a solid basis for SMEs to develop strategic collaboration processes with suppliers and business partners which combine complementary resources in a synergistic manner and generate higher rents for all partners (Cragg et al. 2013; Sanders 2005; Seggie et al. 2006). Strategic collaboration is tacit and complex in nature and is hard to achieve when a firm acts alone (Kim et al. 2006). The sustainability of strategic advantage associated with IT-business alignment depends on how IT is employed to support firm processes and to facilitate the development and use of complementary capabilities (Chen et al. 2015; Setia and Patel 2013). SMEs with tight IT-business alignment can understand how to employ IT strategically to further enhance collaboration with their business partners and foster relational capability (Levy and Powell 2005; Raymond and Bergeron 2008). The pursuit of IT and business alignment enables SMEs to make inclusive decisions which are fully supportive of collaboration across firms (Kraatz and Zajac 2001). Aligning IT and business strategy fosters mutual respect and trust relationships among SMEs, thus facilitating collaboration (Cheng 2011; Terjesen et al. 2011). Thus, we hypothesize that:

H1: IT-business alignment is related positively to strategic collaboration.

IT-business alignment also enables SMEs to leverage integrated IT systems for coordination activities (Setia and Patel 2013). Leveraging IT to increase coordination entails complex adaptations to processes, practices, and strategic initiatives. IT-business alignment enables such adaptations. Coordination is essential to transform operations through discussion about reconfiguring plans, strategies, structures, processes, products and services (Rosenzweig 2009). IT-business alignment facilitates a variety of operational activities in an aligned fashion so as to contribute to meeting SMEs' strategic needs (Raymond and Bergeron 2008). For example, IT-business alignment enables firms to embed IT tightly with business processes (Tallon 2011), facilitating manufacturing (Oh and Pinsonneault 2007), delivery (DeGroote and Marx 2013), and new product development (Cheng et al. 2014). SMEs with higher levels of IT-business alignment are more likely to leverage integrated IT systems in fostering strategic coordination in order to reconfigure operational plans and implement strategic initiatives (Cragg et al. 2011). Thus, we hypothesize that:

H2: IT-business alignment is related positively to coordination. 
In today's information-intensive environment, the integration of IT with business strategy contributes to smooth and effective information flow of knowledge and resource sharing across firms (Kearns and Lederer 2003). ITbusiness alignment creates virtuous cycles as the search for new IT and business opportunities promotes new knowledge sharing (Coltman et al. 2015). Tightly coupled IT and business strategy is associated with beneficial continuous IT-based innovations and radical process changes (Kim et al. 2006; Wu et al. 2006). Disruptive innovation requires radical adjustments to business processes and information systems. The effective, efficient, and responsive translation of this process necessitates a convergence of IT and business strategy. Moreover, tight alignment between IT and business units is essential for an effective response to dyanmic markets (Lu and Ramamurthy 2011). IT-business alignment enables SMEs to make informal and improvised decisions and foster their business processes to be responsive and flexible in turbulent environments (Tallon and Pinsonneault 2011). The synergy between IT and business strategy provides SMEs with opportunities for joint translation of valuable market knowledge into both implicit and explicit strategies which are useful for responding to market, customer, and environmental changes (Cataldo and McQueen 2015). Thus, we hypothesize that:

\section{H3: IT-business alignment is related positively to responsiveness.}

Developing strategic relationships with business partners is increasingly recognized as an important source of competitive advantage as firms are required to work together more closely to meet the challenges of uncertain and volatile markets (Bruns 2013; Dyer and Singh 1998; Rai and Tang 2010). Effective and efficient collaborative activities help SMEs to accommodate market changes or customer requests in a timely manner through information exchange and coordination activities (Arend 2006; Martinsons 2008). Strategic collaboration helps SMEs to work together to plan and execute collaborative operations (Palomero and Chalmeta 2012; Rezaei et al. 2014). Such collaboration allows SMEs to increase the intensity and enrich the quality of their interactions with partners and suppliers, and align supply and demand efficiently (Autry et al. 2010; Oh et al. 2012). These collaborative activities reinforce a SME's ability not only to maintain, advance, and strengthen its current relationships, but also to facilitate coordinated activities in a timely, accurate, and cost effective manner (Jones et al. 2014). Thus, we hypothesize that:

\section{H4: Strategic collaboration is related positively to coordination.}

The literature identifies three principal ways in which strategic collaboration activities enhance responsiveness. First, collaboration with business partners can facilitate responsiveness because it helps companies to share information in a timely manner, schedule procurement, production, and distribution operations synchronously, and thus respond to market changes swiftly (Gulati et al. 2012; Kim and Lee 2010). Second, because critical resources often span firm boundaries and are embedded in the routines and processes, strategic collaboration can help managers to pinpoint resource deficiencies and strengths so as to quickly redirect or assign resources to the most appropriate areas that can take advantage of opportunities(Lavie and Rosenkopf 2006). In this case, firms are more likely to be agile when responding to changes. Third, responsiveness can be enhanced when firms utilize existing resources to exploit and to explore new opportunities (Gupta et al. 2006; He and Wong 2004). Collaboration-induced exploration and exploitation activities can foster the creation of organizational capability that cultimates in an identification of innovative ways to deploy and combine resources, which fosters responsivesses (Voss and Voss 2013). Thus, we hypothesize that:

\section{H5: Strategic collaboration is related positively to responsiveness.}

Coordination consists of transactional related activities between firms and business partners (Kim et al. 2006). Coordination enables SMEs to streamline and automate their operational activities with their business partners effectively and efficiently (Theyel 2013). It facilitates design, manufacturing, quick and reliable delivery of products/services when and where needed (Raymond and Bergeron 2008). Coordination allows SMEs to share the decision roles, rights, and responsibilities on how to reengineer business processes and routines across organizational boundaries (Carlo et al. 2012). Such processes help partner firms to create the mutual understanding of management decisions and to share risks and resources together (Cragg et al. 2011). Therefore, coordination helps SMEs to enhance responsiveness by jointly exploring new markets, developing new products and services, and becoming more responsive to market changes (Wang et al. 2015). Thus, we hypothesize that:

H6: Coordination is related positively to responsiveness. 
In contemporary volatile marketplaces, responsiveness is an imperative for firms to constantly collect, monitor and process changing environmental signals, to quickly adjust processes to capitalize on market opportunities, and to achieve sustainable competitive advantage (Sambamurthy et al. 2003). Responsiveness reflects a firm's ability to collaborate with its business partners in order to build complementary resources and develop knowledge sharing routines, thereby jointly managing and responding to market changes (DeGroote and Marx 2013; Lu and Ramamurthy 2011). Responsiveness underscores a process outcome of shared efforts on collaboration and coordination among partner firms in response to external market changes (Sardana et al. 2016). A responsive firm can distinguish itself from competitors by bundling and mobilizing resources not only to respond in a timely fashion to changes in customer need and competitor strategic moves, but also to launch new products/services more quickly to markets (Sardana et al. 2016; Shin et al. 2015). Responsiveness can improve performance by expanding a firm's repertoire of competitive actions and the nature of its feasible responses to environmental change (Teece et al. 2016). A direct positive relationship between responsiveness and firm performance has been observed (Roberts and Grover 2012). These studies suggest that responsiveness not only improves sales (DeGroote and Marx 2013), market share (Kim and Lee 2010), and profitability (Shin et al. 2015), but also enhances efficiency of product and service delivery (Yang 2014), cost reduction (Chen and Chiang 2011), and customer satisfaction (Yusuf et al. 2014). The SME literature (Jansen et al. 2013; Jones et al. 2014; Lambert and Schwieterman 2012) suggests that entrepreneurial SMEs are innovation-oriented, and often proactively engage in strategic partnership development. Such strategic partnerships can help SMEs to develop responsiveness which not only enables them to respond to new market opportunities, but also helps them to achieve wider benefits such as increased sales, revenues, profitability, cost avoidance, market growth, and new product development (Carlo et al. 2012; Raymond and Bergeron 2008; Voss and Voss 2013). Given that responsiveness is facilitated by the efficacy of robust IT-enabled, repetitive collaboration and coordination processes, SMEs endowed with superior responsiveness competency can outperform competitors through efficient order handling procedures and short delivery lead time, therefore achieving customer service performance (Woldesenbet et al. 2012). Thus, we hypothesize that:

H7: Responsiveness is related positively to SME performance.

\section{Research Methodology}

The data used for testing our hypothesized model was collected through an online survey of 679 Australian fast growth SMEs compiled by Business Review Weekly (BRW). Key inclusion criteria for SMEs to enter the BRW fast growth project are that their previous year's turnover must exceed AUD\$500,000; they must have fewer than 200 full-time employees; they cannot be a subsidiary of an Australian or overseas corporation; and they must not receive more than $50 \%$ of their revenue from a single client. Key informants were CEOs/Founders who were an essential source of information because they were involved in making IT investment decisions, and were exposed to the views of peers and subordinates regarding the performance of IT investments. Participants were invited to complete an online questionnaire in response to a personalized email highlighting the academic nature of the study. A follow-up email was sent three weeks after the initial one, and a second reminder email was sent two weeks later. Respondents were assured of confidentiality. Of the sample, 211 completed questionnaires were received, a response rate of $31.1 \%$. Key industry representation included Property \& Business Services, Information Technology, Personal and Other Services, Finance and Insurance, Communications, Construction, Retail Trade. We tested the sample for non-response bias, using the approach suggested by Armstrong and Overton (1977). Differences in responses to all the constructs between early respondents (i.e., those that completed the survey upon the first invitation) and late respondents (i.e., those who replied to follow-up emails) were compared. Independent sample t-tests on each construct failed to reveal significant differences between early and late respondents (all ps>.05), suggesting that non-response bias was not an issue.

\subsection{Common Method Bias}

In this study, we tested common method bias using the structural equation modeling (SEM) procedures recommended by Podsakoff et al. (2003). First, we conducted a Harman one-factor test to estimate the extent of the bias. Principal components analysis resulted in five components, accounting for $79.2 \%$ of the total variance. The first component explained only $21.3 \%$ of the variance, implying the absence of a dominant general factor that accounts for more than $50 \%$ of the variation. Second, this study controlled for the effects of a directly measured social desirability factor (Marlowe and Crowne 1961). Results culminated in a poor fitting model entailing associations between social desirability and model parameters, with all path coefficients being close to 
zero and non-significant (all ps>0.05). Accordingly, social desirability does not contribute significantly to the model, suggesting that there is no common method bias.

\subsection{Constructs}

We operationalize the constructs based on the literature. All constructs were assessed with seven-point Likert scales ranging from Strongly Disagree (1) and Strongly Agree (7). Specifically, four items measuring IT-business alignment were adapted from Kearns and Sabherwal (2006), assessing the extent to which IT and business strategies reflect each other. Three items measuring strategic collaboration were adapted from Kim and Lee (2010), capturing the degree of strategic planning and forecasting activities between a company and its business partners/suppliers. Three items measuring coordination were adapted from Wu et al. (2006), reflecting transaction-related activities for the purpose of fulfilling customer orders between firms and their business partners/suppliers. Three items measuring responsiveness were adapted from Kim and Lee (2010), reflecting a firm's ability to scan and process of extensive amounts of information in order to identify and anticipate external changes, and also to continuously monitor and quickly improve product/service offerings in response to market and customer needs. We measured the dependent variable - SME performance - in terms of growth in sales, profit, and revenues, new product development, and customer service, using the scales adapted from Morgan et al. (2009). As control variables, we employed the number of employees to measure firm size, number of years since business start-up to measure firm age and used a series of industry dummies to control for exogenous factors at the industry level. The elements of the questionnaire designed to measure the constructs are presented in Appendix.

\subsection{Data Analysis}

Data were analyzed with AMOS 25.0, using confirmatory factor analysis (CFA) procedures with the maximum likelihood (ML) estimation method. Prior to conducting the CFA, we ran an exploratory factor analysis (EFA) on all indicators. Principal axis factoring with direct oblimin rotation yielded consistent groupings with our hypothesized measurement models. All constructs were tested for reliability, validity, and fit. Based on an assessment of CFA fit statistics, measurement models were further refined to obtain sound fit. Respectively, Tables 1 and 2 show correlations and descriptive statistics and measurement properties of constructs. In this study, indicator reliability values range between .50 and .90 , composite reliability values exceed the recommended value of .70 (Nunnally and Bernstein 1994), and all variance extracted estimates exceed the recommended value of .50 (Hair et al. 2006). Values for t-statistics for all factor loadings were found to be significant (all ps<.001), indicating that measures satisfy convergent validity criteria (Gefen et al. 2000). In addition, average variance extracted for each construct was greater than the squared correlation between constructs, providing evidence for discriminant validity (Fornell and Larcker 1981).

Table 1: Correlation Matrix, Mean Scores and Standardized Deviations

\begin{tabular}{lccccccc}
\hline & Mean & SD & 1 & 2 & 3 & 4 & 5 \\
\hline 1. IT-businss Alignment (ITAL) & 5.23 & 1.38 & .83 & & & & \\
2. Strategic Collaboration (SCOL) & 4.39 & 1.57 & $.37^{* *}$ & .90 & & & \\
3. Coordination (COOR) & 4.43 & 1.22 & $.51^{* *}$ & $.43^{* *}$ & .85 & & \\
4. Respsonsiveness (RESP) & 5.38 & 1.13 & $.49^{* *}$ & $.33^{* *}$ & $.52^{* *}$ & .75 & .77 \\
5. SME Performance (SMEP) & 5.42 & 1.07 & $.44^{* *}$ & $.40^{* *}$ & $.57^{* *}$ & $.62^{* *}$ & .77 \\
\hline
\end{tabular}

Note. (1) *p<.05. **p<.01. (2) The diagonal elements are the square root of the AVE.

Table 2: Confirmatory Factor Analysis: Standardized Loadings and Reliability

\begin{tabular}{|c|c|c|c|c|c|}
\hline Constructs & Cronbach's $\alpha$ & $\begin{array}{l}\text { Construct } \\
\text { Reliability }\end{array}$ & $\begin{array}{l}\text { Variance } \\
\text { Extraction }\end{array}$ & $\begin{array}{l}\text { Range of } \\
\text { Standardized } \\
\text { Loadings }\end{array}$ & $\begin{array}{l}\text { Range of } \\
\text { Indicator } \\
\text { Reliability }\end{array}$ \\
\hline 1. IT-businss Alignment & .89 & .90 & .69 & $.71-.95$ & $.50-.90$ \\
\hline 2. Strategic Collaboration & .92 & .92 & .80 & $.84-.93$ & $.71-.87$ \\
\hline 3. Coordination & .88 & .89 & .72 & $.79-.90$ & $.62-.81$ \\
\hline 4. Respsonsiveness & .81 & .80 & .56 & $.73-.77$ & $.56-.79$ \\
\hline 5. SME Performance & .84 & .84 & .58 & $.71-.89$ & $.50-.79$ \\
\hline
\end{tabular}

Note. All factor loadings are significant at $p<.001$ level

\section{Results}

Given the acceptable measurement models, we estimated a full latent variable structural model using multiple indices: $\chi^{2} / \mathrm{df}$ ratio < 3; CFI and TLI > .90; SRMR < .08; and RMSEA < .08 (Hair et al. 2006). The hypothesized 
structural model indicated a good model fit to data: $\chi^{2}(127)=304.941, \chi^{2} / \mathrm{df}=2.401, \mathrm{CFI}=.954, \mathrm{TLI}=.945$, $\mathrm{SRMR}=.061$, RMSEA $=.072$. An examination of the structural parameter estimates suggests that IT-business alignment has positive impacts on strategic collaboration, coordination, and responsiveness, thus supporting $\mathrm{H} 1$ $(\beta=.31, p<.001), H 2(\beta=.35, p<.001)$, and $H 3(\beta=.24, p<.001)$. Strategic collaboration positively facilitates coordination and responsiveness, supporting $H 4(\beta=.37, p<.001)$ and $H 5(\beta=.15, p<.05)$. Coordination impacts positively on responsiveness, supporting $\mathrm{H} 6(\beta=.42, p<.001)$. Responsiveness is related positively and significantly to SME performance, thus supporting $\mathrm{H} 7(\beta=.72, p<.001)$. Hence these various parameters are significant at the five percent level and the data support the conclusion that the structural model is a good fit. The squared multiple correlation (SMC) values, which are similar to $\mathrm{R}^{2}$ in regression analysis, show that this model accounts for $21 \%$ of the variance in strategic collaboration, $34 \%$ of the variance in coordination, $41 \%$ of the variance in responsiveness, and $52 \%$ of the variance in SME performance. Among control variables, none of them showed significant effects in the research model.

To test the mediating effects of strategic collaboration, coordination, and responsiveness, we followed the three-step method suggested by Baron and Kenny (1986). First, the direct link between IT-business alignment (independent variable) and firm performance (dependent variable) was significant and thus satisfied the first condition for mediating effects (Table 3). Further, the links between IT-business alignment (independent variable) and strategic collaboration (mediator1), coordination (mediator2), responsiveness (mediator3) were significant; and the link between responsiveness (mediator3) and firm performance (dependent variable) was significant (Table 3), therefore they satisfied the second condition for the existence of mediating effects. In addition, the direct relationship between IT-business alignment (independent variable) and firm performance (dependent variable), became insignificant when we added the link between responsiveness (mediator3) and firm performance (dependent variable), while the latter link was significant. Therefore, the results showed that strategic collaboration, coordination, and responsiveness fully mediated the relationship between IT-business alignment and firm performance. Tables 4 and 5 show the total effects and indirect effects of the mediating tests.

Table 3: Results of Mediating Effects Tests

\begin{tabular}{|l|l|l|l|l|l|l|l|l|l|l|l|}
\hline & & & & & & & \multicolumn{3}{|c|}{ IV+M1+M2+M3->DV } & \\
\hline IV & M1 & M2 & M3 & DV & IV->DV & IV->M1 & IV->DV & M1->M2 & M2->M3 & M3->DV & Mediating \\
\hline ITAL & SCOL & COOD & RESP & SMEP & $.49^{* * *}$ & $.31^{* * *}$ & .03 & $.37 * * *$ & $.42^{* * *}$ & $.72^{* * *}$ & Full \\
\hline
\end{tabular}

Table 4: Standardized Total Effects

\begin{tabular}{lcccc}
\hline & ITAL & SCOL & COOR & RESP \\
\hline SCOL & 0.31 & 0 & 0 & 0 \\
COOR & 0.46 & 0.37 & 0 & 0 \\
RESP & 0.47 & 0.27 & 0.42 & 0 \\
SMEP & 0.34 & 0.20 & 0.30 & 0.72 \\
\hline
\end{tabular}

Table 5: Standardized Indirect Effects

\begin{tabular}{lcccc}
\hline & ITAL & SCOL & COOR & RESP \\
\hline SCOL & 0 & 0 & 0 & 0 \\
COOR & 0.12 & 0 & 0 & 0 \\
RESP & 0.24 & 0.15 & 0 & 0 \\
SMEP & 0.38 & 0.22 & 0.30 & 0 \\
\hline
\end{tabular}

\section{Discussion}

There are several key findings in this study. First, our results show that IT-business alignment is related positively to SME performance through the development of business competences. The findings are consistent with the theoretical arguments contended by Sambamurthy et al. (2003) regarding the role of IT-enabled digital options in creating business advantages in terms of collaboration, coordination, and responsiveness. However, it should be noted that although IT may be critical in realizing business value, huge IT investment does not assure business advantages all the time (Weill et al. 2002). Instead, in order to achieve business benefits, firms should engage in 
IT-business strategic thinking, integrate IT-business planning, and establish IT-business synergy in order to understand what key resources are needed for what strategic initiatives, and then identify how to employ these resources to the right business initiatives so as to realize and maximize IT investment value.

Second, our results indicate that collaboration and coordination are positively associated with SME responsiveness. These results suggest that responsiveness benefits from collaboration and coordination between firms and the integration of IT-enabled activities across businesses eliminates barriers to consensus that can impede responsiveness (Ashurst et al. 2011; Chakravarty et al. 2013). These findings demonstrate that the key competences SMEs gain from IT-enabled partnership processes originate from effectively leveraging, collaborating, and coordinating resources across firms. These competences are critical for SMEs to compete in rapidly fast changing environments (Dutot et al. 2014; Reid et al. 2016).

Third, our results suggest that the inter-mediate business processes (i.e., strategic collaboration, coordination, responsiveness) fully mediate the link between IT-business alignment and SME performance. The findings indicate that the ultimate value of IT lies in how IT-business alignment enables SMEs to strategically deploy resources in core competences and prepares firms for change. IT-business alignment is not only about past performance but also about future firm performance which is affected by the pace of responsiveness to change (Martinsons et al. 1999; Tallon and Pinsonneault 2011). Although responsiveness is essential for firms to survive in volatile business environments, IT-business alignment can be regarded as an antecedent, enabling SMEs to extract enduring value from IT following each market change (Chao and Chandra 2012; Cragg et al. 2011).

This study provides three contributions and implications for research. First, this study contributes to research by providing empirical evidence through an examination of the link between IT-business alignment, strategic collaboration, coordination, responsiveness, and SME performance. Findings of this study suggest the enabling role of IT-business alignment in improving SME performance and extend our understanding of alignmentperformance link in the SME context. The conceptualization in investigating the effect of IT-business alignment at the business process level provide a new insight to understand how and why alignment influences performance.

Second, this study contributes to research by investigating IT value creation in the SME context. While a plethora of studies have been conducted to explore the alignment-performance link, our understanding of the underlying influential mechanisms on IT-business alignment in the SME context still remains limited. Particularly, when a firm is entrepreneurial, the existence of slack resources promotes its innovative behaviour, creativity and experimentation, and growth (Brekke 2015; Macpherson et al. 2015; Nambisan 2017). Our findings indicate that this cohort of companies employs IT-business alignment as a strategic tool, focuses IT-enabled efforts on critical areas, and effectively aligns IT with strategic purposes and market positions so as to achieve outstanding ITbased competitive advantage. Our study also implies that entrepreneurial SMEs adopt a proactive IT stance, engage in a well aligned IT-business strategy to experiment with, and explore new and available technologies to exploit existing competencies, address, and create new business opportunities (Del Giudice and Straub 2011; Hedman et al. 2016; Ojala 2016).

Third, our findings have implications for IS research which emphasizes the complementary effect between IT and non-IT resources as source of competitive advantage. Previous study (Raymond and Bergeron 2008) finds that the locus of alignment can vary from process to process, depending on the particular strategy a SME has chosen. When firms attempt to emulate an IT-based strategic advantage, the association of alignment with responsiveness may be causally ambiguous (Tallon and Pinsonneault 2011). Research that aims to explore the effect of IT-business alignment on business processes may consider how IT-business alignment interacts with business strategy to generate benefits. By conceptualizing and studying alignment at a specific and disaggregated level can yield a more comprehensive understanding of the relationship between alignment, strategy, and performance.

Our findings also have three implications for SME business practices. First, IT-business alignment is a valuable advantage-producing resource, ensuring SME business success. IT-business alignment allows SMEs to leverage IT wisely in the strategic areas which satisfy their business goals while developing great knowledge and awareness of how IT can help these companies react quickly to changing markets. IT-business alignment can be a source of competitive advantage for SMEs. Prior research (Kearns and Lederer 2003; Ping-Ju Wu et al. 2015; Preston and Karahanna 2009) shows that managers that share an understanding of the role of IT in business 
processes promote IT-business alignment. As such, SME managers should work together intensively to be more apt to sense market opportunities or threats and to build a consensus around how best to react.

Second, in the current context of volatile business environments, it is imperative for firms to develop responsiveness so as to respond to environmental challenges and capitalize on business opportunities. In this case, SME managers should regard responsiveness as an imperative for their business to compete, succeed, and thrive in rapidly changing environments. Aligning IT with business strategy enhances IT use in a firm's core processes, which promotes responsiveness. While IT-business alignment plays a critical role in IT-based value creation, responsiveness is an expanded IT value metric (Lu and Ramamurthy 2011). SME managers can consider employing alignment to develop digital options which help firms to speed up decision making, facilitate communication, and respond quickly to changing conditions.

Third, strategic collaboration and coordination activities impact favourably on responsiveness which in turn contributes to business value. Developing strategic relationships provides SMEs with resources for creating inimitable value-generating capabilities, facilitates responsiveness to shifting competitive demands of market environments, and thus promoting firm growth (Altinay et al. 2016; Bamiatzi and Kirchmaier 2014; Parida et al. 2017). Nowadays, digital technologies interconnect business environments on a global scale and firms are no longer working alone. Therefore the competition will no longer be between companies, but between supply chain networks. Accordingly, building such strategic relationships is critical for SMEs to do business in dynamic environments.

This study has four specific limitations. First, we adopt a static cross-sectional research design with data collected at a single point in time. The cross-sectional research design in the current study is limited in addressing processoriented issues or causal relationships. A longitudinal design would be desirable to further delineate the causal dynamics between alignment and responsivenss.

Second, we use a single-informant (CEO/Founder) in each responding company and their perceptions of IT business value as proxy measures of performance. Future research might also consider obtaining data from different groups of respondents such as managers across production, marketing, and operation functions. This would permit the collection of more detailed contextual information about IT use within and across firms which will inform hypothesis development, data analysis and interpretation, and the reportage of research (Johns 2006).

A third limitation relates to sample characteristics upon which the present hypotheses are tested. This study is drawn from a proportion of SMEs in a specific geographic region. While the present hypothesized model might be applicable to larger firms as well as SMEs in other geographic locales, further research is needed to confirm the generalizability of findings to other contexts.

Finally, this is a study of the effect of IT-business alignment on SME performance using quantitative methods. Future research could employ a series of case studies. Such case studies of strategic IT-business alignment process effectively achieved in SMEs could offer more comprehensive understanding of IT-business alignment principles, policies, and practices, and therefore provide added robustness to the nomological network and enhance knowledge on strategic IT management in the SME context (Raymond et al. 2019).

\section{Conclusion}

Despite many previous studies exploring the relationship between IT-business alignment and firm performance, added empirical evidence is needed to provide further, more integrated knowledge of IT-business alignment phenomenon, its strategic benefits, and performance outcomes in the context of SMEs. Focusing on this gap, we develop and empirically test a hypothesized model integrating IT-business alignment, strategic collaboration, coordination, responsiveness, and SME performance. Our results indicate that IT-business alignment has substantial effects on the improvements of business competences (i.e., strategic collaboration, coordination, responsiveness) which promote SME growth. Our results also suggest that these intermediate business processes fully mediate the link between IT-business alignment and SME performance. Hence IT-business alignment is shown to be a potent source of value and worthy of the priority status consistently afforded it by managers. SMEs should continuously engage in IT-business alignment to successfully manage and leverage their IT resources. This will build business core process competences and thereby enhance the prospects of business 
success. This study contributes to the IS field by providing a conceptualization for investigating the effect of ITbusiness alignment at the business process level, thus offering new insights to understand how and why alignment influences SME performance. We hope this study will motivate further discussion and advance theory to generate more holistic and comprehensive knowledge about strategic IT management practices in the SMEs.

\section{References}

Altinay, L., Madanoglu, M., De Vita, G., Arasli, H., and Ekinci, Y., 2016. The Interface between organizational learning capability, entrepreneurial orientation, and SME growth. Journal of Small Business Management, 54(3), pp. 879-891.

Arend, R.J., 2006. SME-supplier alliance activity in manufacturing: contingent benefits and perceptions. Strategic Management Journal, 27(8), pp. 741-763.

Armstrong, J.S. and Overton, T.S., 1977. Estimating nonresponse bias in mail surveys. Journal of Marketing Research, 14(3), pp. 396-402.

Ashurst, C., Cragg, P. and Herring, P., 2011. The role of IT competences in gaining value from e-business: An SME case study. International Small Business Journal, 30(6), pp. 640-658.

Aslesen, H.W. and Harirchi, G., 2015. The effect of local and global linkages on the innovativeness in ICT SMEs: does location-specific context matter?. Entrepreneurship \& Regional Development, 27(9-10), pp. 644-669.

Autry, C.W., Grawe, S.J., Daugherty, P.J. and Richey, R.G., 2010. The effects of technological turbulence and breadth on supply chain technology acceptance and adoption. Journal of Operations Management, 28(6), pp. 522-536.

Bamiatzi, V.C. and Kirchmaier, T., 2014. Strategies for superior performance under adverse conditions: A focus on small and medium-sized high-growth firms. International Small Business Journal, 32(3), pp. 259-284.

Baron, R.M. and Kenny, D.A., 1986. The moderator-mediator variable distinction in social psychological research:Conceptual, strategic and statistical considerations. Journal of personality and social psychology, 51(6), pp. $1173-1182$.

Bergeron, F., Croteau, A.M., Uwizeyemungu, S. and Raymond, L., (eds) 2020. A framework for research on information technology governance in SMEs, Start-Ups and SMEs: Concepts, Methodologies, Tools, and Applications. IGI Global.

Bharadwaj, A., El Sawy, O.A., Pavlou, P.A. and Venkatraman, N., 2013. Digital business strategy: toward a next generation of insights. MIS Quarterly, 37(2), pp. 471-482.

Bordonaba-Juste, V. and Cambra-Fierro, J.J., 2009. Managing supply chain in the context of SMEs: a collaborative and customized partnership with the suppliers as the key for success. Supply Chain Management: An International Journal, 14(5), pp. 393-402.

Brekke, T., 2015. Entrepreneurship and path dependency in regional development. Entrepreneurship \& Regional Development, 27(3-4), pp. 202-218.

Brouthers, K.D., Nakos, G. and Dimitratos, P., 2015. SME entrepreneurial orientation, international performance, and the moderating role of strategic slliances. Entrepreneurship Theory and Practice, 39(5), pp. 1161-1187.

Bruns, H.C., 2013. Working alone together: Coordination in collaboration across domains of expertise', Academy of Management Journal, 56(1), pp. 62-83.

Carlo, J.L., Lyytinen, K. and Rose, G.M. 2012. A knowledge-based model of radical innovation in small software firms. MIS Quarterly, 36(3), pp. 865-A810.

Cataldo, A., McQueen, R. and Hardings, J., 2012. Comparing strategic IT alignment versus process IT Alignment in SMEs. Journal of Research and Practice in Information Technology, 44(1), pp. 43-57.

Cataldo, A. and McQueen, R.J., 2015. IT alignment in SMEs: should it be with strategy or process?. Australasian Journal of Information Systems, 19, pp. 1-12.

Cenamor, J., Parida, V. and Wincent, J., 2019. How entrepreneurial SMEs compete through digital platforms: The roles of digital platform capability, network capability and ambidexterity. Journal of Business Research, 100, pp. 196-206.

Chakravarty, A., Grewal, R. and Sambamurthy, V.M., 2013. Information technology competencies, organizational agility, and firm performance: Enabling and facilitating roles. Information Systems Research, 24(4), pp. 976-997.

Chan, Y., Huff, S., Barclay, D. and Copeland, D., 1997. Business strategic orientation, information systems strategic orientation, and strategic alignment. Information Systems Research, 8(2), pp. 125-150.

Chan, Y., Sabherwal, R. and Thatcher, J.B., 2006, Antecedents and outcomes of strategic IS alignment: an empirical investigation. IEEE Transactions on Engineering Management, 53(1), pp. 27-47.

Chan, Y.E. and Reich, B.H., 2007. IT alignment: an annotated bibliography. Journal of Information Technology, 22(4), pp. 316-396.

Chang, H-L., Wang, K. and Chiu, I., 2008. Business-IT fit in e-procurement systems: Evidence from high-technology firms in China. Information Systems Journal, 18(4), pp. 381-404.

Chao, C.A. and Chandra, A., 2012. Impact of owner's knowledge of information technology (IT) on strategic alignment and IT adoption in US small firms. Journal of Small Business and Enterprise Development, 19(1), pp. 114-131.

Chen, D.Q., Mocker, M., Preston, D.S. and Teubner, A., 2010. Information Systems Strategy: Reconceptualization, Measurement, and Implications. MIS Quarterly, 34(2), pp. 233-A238.

Chen, M., Liu, H., Wei, S. and Gu, J., 2018.'Top managers' managerial ties, supply chain integration, and firm performance in China: A social capital perspective. Industrial Marketing Management, 74, pp. 205-214.

Chen, W-H. and Chiang, A-H., 2011. Network agility as a trigger for enhancing firm performance: A case study of a high-tech firm implementing the mixed channel strategy. Industrial Marketing Management, 40(4), pp. 643-651. 
Chen, Y., Wang, Y., Nevo, S., Benitez-Amado, J. and Kou, G., 2015. IT capabilities and product innovation performance: The roles of corporate entrepreneurship and competitive intensity. Information \& Management, 52(6), pp. 643-657.

Cheng, J-H., 2011. Inter-organizational relationships and information sharing in supply chains. International Journal of Information Management, 31(4), pp. 374-384.

Cheng, J-H., Chen, M-C. and Huang, C-M., 2014. Assessing inter-organizational innovation performance through relational governance and dynamic capabilities in supply chains. Supply Chain Management: An International Journal, vol. 19, no. 2, pp. 173-186.

Coltman, T, Tallon, P, Sharma, R and Queiroz, M., 2015. Strategic IT alignment: twenty-five years on. Journal of Information Technology, 30(2), pp. 91-100.

Corral de Zubielqui, G., Lindsay, N., Lindsay, W. and Jones, J., 2019. Knowledge quality, innovation and firm performance: a study of knowledge transfer in SMEs. Small Business Economics, 53(1), pp. 145-164.

Cragg, P., Caldeira, M. and Ward, J., 2011. Organizational information systems competences in small and medium-sized enterprises. Information \& Management, 48(8), pp. 353-363.

Cragg, P., Mills, A. and Suraweera, T., 2013. The Influence of IT Management Sophistication and IT Support on IT Success in Small and Medium-Sized Enterprises. Journal of Small Business Management, 51(4), pp. 617-636.

Cui, M. and Pan, S.L., 2015. Developing focal capabilities for e-commerce adoption: A resource orchestration perspective. Information \& Management, 52(2), pp. 200-209.

Cui, T., Ye, H., Teo, H.H. and Li, J., 2015. Information technology and open innovation: A strategic alignment perspective. Information \& Management, 52(3), pp. 348-358.

DeGroote, S.E. and Marx, T.G., 2013. The impact of IT on supply chain agility and firm performance: An empirical investigation. International Journal of Information Management, 33(6), pp. 909-916.

Del Giudice, M. and Straub, D., 2011. IT and entrepreneurism: An on-again, off-again love affair or a marriage?. MIS Quarterly, 35(4), pp. III-VII.

Dong, J.Q. and Yang, C-H., 2015. Information technology and organizational learning in knowledge alliances and networks: Evidence from U.S. pharmaceutical industry. Information \& Management, 52(1), pp. 111-122.

Du, J. and Temouri, Y., 2015. High-growth firms and productivity: evidence from the United Kingdom. Small Business Economics, 44(1), pp. 123-143.

Dutot, V., Bergeron, F. and Raymond, L., 2014. Information management for the internationalization of SMEs: An exploratory study based on a strategic alignment perspective. International Journal of Information Management, 34(5), pp. 672-681.

Dyer, J.H. and Singh, H., 1998. The relational view: Cooperative strategy and sources of interorganizational competitive advantage. Academy of Management Review, 23(4), pp. 660-679.

Engel, Y., Kaandorp, M. and Elfring, T., 2017. Toward a dynamic process model of entrepreneurial networking under uncertainty. Journal of Business Venturing, 32(1), pp. 35-51.

Flynn, B.B., Huo, B. and Zhao, X., 2010. The impact of supply chain integration on performance: A contingency and configuration approach. Journal of Operations Management, 28(1), pp. 58-71.

Fornell, C. and Larcker, D.F., 1981. Evaluating structural equation models with unobservable variables and measurement error. Journal of Marketing Research, 18(1), pp. 39-50.

Gefen, D., Straub, D.W. and Bourdreau, M.C., 2000. Structural equation modeling and regression: Guidelines for research practices. Communications of the AIS, 4(7), pp. 1-78.

Gulati, R., Wohlgezogen, F. and Zhelyazkov, P., 2012. The two facets of collaboration: Cooperation and coordination in strategic alliances. The Academy of Management Annals, 6(1), pp. 531-583.

Gupta, A.K., Smith, K.G. and Shalley, C.E., 2006. The interplay between exploration and exploitation. The Academy of Management Journal, 49(4), pp. 693-706.

Hair, J.F., Black, W.C., Babin, B.J., Anderson, R.E. and Tatham, R.L., 2006. Multivariate data analysis, Prentice Hall, New Jersey.

He, Z-L. and Wong, P-K., 2004. Exploration vs. exploitation: An empirical test of the ambidexterity hypothesis. Organization Science, 15(4), pp. 481-494.

Hedman, J., Sarker, S. and Veit, D., 2016. Digitization in business models and entrepreneurship. Information Systems Journal, 26(5), pp. 419-420.

Huo, B., Zhang, C. and Zhao, X., 2015. The effect of IT and relationship commitment on supply chain coordination: A contingency and configuration approach. Information \& Management, 52(6), pp. 728-740.

Hussin, H., King, M. and Cragg, P., 2002. IT alignment in small firms. European Journal of Information Systems, 11(2), pp. 108-127.

Jansen, R.J.G., Curşeu, P.L., Vermeulen, P.A.M., Geurts, J.L.A. and Gibcus, P., 2013. Information processing and strategic decision-making in small and medium-sized enterprises: The role of human and social capital in attaining decision effectiveness. International Small Business Journal, 31(2), pp. 192-216.

Jespersen, K., Rigamonti, D., Jensen, M.B. and Bysted, R., 2018. Analysis of SMEs partner proximity preferences for process innovation. Small Business Economics, 51(4), pp. 879-904.

Johns, G., 2006. The Essential impact of context on organizational behavior. The Academy of Management Review, 31(2), pp. 386-408. 
Jones, P., Simmons, G., Packham, G., Beynon-Davies, P. and Pickernell, D., 2014. An exploration of the attitudes and strategic responses of sole-proprietor micro-enterprises in adopting information and communication technology. International Small Business Journal, 32(3), pp. 285-306.

Kearns, G.S. and Lederer, A.L., 2003. A resource-based view of strategic IT alignment: How knowledge sharing creates competitive advantage. Decision Sciences, 34(1), pp. 1-29.

Kearns, G.S. and Sabherwal, R., 2006. Strategic alignment between business and information technology: A knowledgebased view of behaviors, outcome, and consequences. Journal of Management Information Systems, 23(3), pp. 129162.

Kim, D., Cavusgil, S.T. and Calantone, R.J., 2006. Information system innovations and supply chain management: Channel relationships and firm performance. Journal of the Academy of Marketing Science, 34(1), pp. 40-54.

Kim, D. and Lee, R.P., 2010. Systems collaboration and strategic collaboration: Their impacts on supply chain responsiveness and market performance. Decision Sciences, 41(4), pp. 955-981.

Koryak, O., Mole, K.F., Lockett, A., Hayton, J.C., Ucbasaran, D. and Hodgkinson, G.P., 2015. Entrepreneurial leadership, capabilities and firm growth. International Small Business Journal, 33(1), pp. 89-105.

Kraatz, M.S. and Zajac, E.J., 2001. How organizational resources affect strategic change and performance in turbulent environments: Theory and evidence. Organization Science, 12(5), pp. 632-657.

Lambert, D.M. and Schwieterman, M.A., 2012. Supplier relationship management as a macro business process. Supply Chain Management: An International Journal, 17(3), pp. 337-352.

Lavie, D. and Rosenkopf, L., 2006. Balancing exploration and exploitation in alliance formation. Academy of Management Journal, 49(4), pp. 797-818.

Lechner, C. and Gudmundsson, S.V., 2014. Entrepreneurial orientation, firm strategy and small firm performance. International Small Business Journal, 32(1), pp. 36-60.

Levy, M. and Powell, P., 2005. Strategies for growth in SMEs: The role of information and information systems, Elsevir Butterworth-Heinemann, Oxford.

Liao, J., Welsch, H. and Stoica, M., 2003. Organizational absorptive capacity and responsiveness: An empirical investigation of growth-oriented SMEs. Entrepreneurship Theory and Practice, 28(1), pp. 63-86.

Liu, H., Huang, Q., Wei, S. and Huang, L., 2015. The impacts of IT capability on internet-enabled supply and demand process integration, and firm performance in manufacturing and services. The International Journal of Logistics Management, 26(1), pp. 172-194.

Lu, Y. and Ramamurthy, K., 2011. Understanding the link between information technology capability and organizational agility: An empirical examination. MIS Quarterly, 35(4), pp. 931-954.

Luftman, J., Lyytinen, K. and Zvi, T.B., 2015. Enhancing the measurement of information technology (IT) business alignment and its influence on company performance. Journal of Information Technology, pp. 1-21.

Macpherson, A., Herbane, B. and Jones, O., 2015. Developing dynamic capabilities through resource accretion: expanding the entrepreneurial solution space. Entrepreneurship \& Regional Development, 27(5-6), pp. 259-291.

Marlowe, D. and Crowne, D.P., 1961. Social desirability and response to perceived situational demands. Journal of Consulting Psychology, 25, pp. 109-115.

Martinsons, M., Davison, R. and Tse, D., 1999. The balanced scorecard: a foundation for the strategic management of information systems. Decision Support Systems, 25(1), pp. 71-88.

Martinsons, M.G., 2008. Relationship-based e-commerce: theory and evidence from China. Information Systems Journal, 18(4), pp. 331-356.

Morgan, N.A., Vorhies, D.W. and Mason, C.H., 2009. Market orientation, marketing capabilities, and firm performance. Strategic Management Journal, 30(8), pp. 909-920.

Nambisan, S., 2017, Digital entrepreneurship: Toward a digital technology perspective of entrepreneurship. Entrepreneurship Theory and Practice, 41(6), pp. 1029-1055.

Nunnally, J.C. and Bernstein, I.H., 1994. Psychometric Theory, McGraw Hill, New York.

Oh, L-B., Teo, H-H. and Sambamurthy, V., 2012. The effects of retail channel integration through the use of information technologies on firm performance. Journal of Operations Management, 30(5), pp. 368-381.

Oh, W. and Pinsonneault, A., 2007. On the assessment of the strategic value of information technologies: conceptual and analytical approaches. MIS Quarterly, 31(2), pp. 239-265.

Ojala, A., 2016. Business models and opportunity creation: How IT entrepreneurs create and develop business models under uncertainty. Information Systems Journal, 26(5), pp. 451-476.

Palomero, S. and Chalmeta, R., 2012. A guide for supply chain integration in SMEs. Production Planning \& Control, 25(5), pp. 372-400.

Parida, V., Pesämaa, O., Wincent, J. and Westerberg, M., 2017. Network capability, innovativeness, and performance: a multidimensional extension for entrepreneurship. Entrepreneurship \& Regional Development, 29(1-2), pp. 94-115.

Ping-Ju Wu, S., Straub, D.W. and Liang, T-P., 2015. How information technology governance mechanisms and strategic alignment influnce organizational performance: Insights from a matched survey of business and IT managers. MIS Quarterly, 39(2), pp. 497-A497.

Podsakoff, P.M., MacKenzie, S.B., Lee, J-Y. and Podsakoff, N.P., 2003. Common method biases in behavioral research: A critical review of the literature and recommended remedies. Journal of Applied Psychology, 88(5), pp. 879-903.

Preston, D.S. and Karahanna, E., 2009. Antecedents of IS strategic alignment: A nomological network. Information Systems Research, 20(2), pp. 159-179. 
Rai, A. and Tang, X., 2010. Leveraging IT capabilities and competitive process capabilities for the management of interorganizational relationship portfolios. Information Systems Research, 21(3), pp. 516-542.

Raymond, L. and Bergeron, F., 2008. Enabling the business strategy of SMEs through e-business capabilities: A strategic alignment perspective. Industrial Management \& Data, 108(5), pp. 577-595.

Raymond, L., Bergeron, F., Croteau, A-M. and Uwizeyemungu, S., 2019. Determinants and outcomes of IT governance in manufacturing SMEs: A strategic IT management perspective. International Journal of Accounting Information Systems, 35, p. 100422.

Reid, M., Hultink, E.J., Marion, T. and Barczak, G., 2016, The impact of the frequency of usage of IT artifacts on predevelopment performance in the NPD process. Information \& Management, 53(4), pp. 422-434.

Rezaei, J., Ortt, R. and Trott, P., 2014. How SMEs can benefit from supply chain partnerships. International Journal of Production Research, 53(5), pp. 1527-1543.

Roberts, N. and Grover, V., 2012. Leveraging information technology infrastructure to facilitate a firm's customer agility and competitive activity: An empirical investigation. Journal of Management Information Systems, 28(4), pp. 231-270.

Rosenzweig, E.D., 2009. A contingent view of e-collaboration and performance in manufacturing. Journal of Operations Management, 27(6), pp. 462-478.

Sabherwal, R. and Chan, Y.E., 2001. Alignment between business and IS strategies: A study of prospectors, analyzers, and defenders. Information Systems Research, 12(1), pp. 11-33.

Sabherwal, R., Hirschheim, R. and Goles, T., 2001. The dynamics of alignment: Insights from a punctuated equilibrium model. Organization Science, 12(2), pp. 179-197.

Sabherwal, R., Sabherwal, S., Havakhor, T. and Steelman, Z., 2019. How does strategic alignment affect firm performance? The roles of information technology investment and environmental uncertainty. MIS Quarterly, 43(2), pp. 453-474.

Sahin, F. and Robinson, E.P., 2005. Information sharing and coordination in make-to-order supply chains. Journal of Operations Management, 23, pp. 579-598.

Sambamurthy, V., Bharadwaj, A. and Grover, V., 2003. Shaping agility through digital options: reconceptualizing the role of information technology in contemporary firms. MIS Quarterly, 27(2), pp. 237-263.

Sanders, N.R., 2005. IT alignment in supply chain relationships: A study of supplier benefits. Journal of Supply Chain Management, 41(2), pp. 4-13.

Sardana, D., Terziovski, M. and Gupta, N., 2016. The impact of strategic alignment and responsiveness to market on manufacturing firm's performance. International Journal of Production Economics, 177, pp. 131-138.

Seggie, S.H., Kim, D. and Cavusgil, S.T., 2006. Do supply chain IT alignment and supply chain interfirm system integration impact upon brand equity and firm performance?. Journal of Business Research, 59(8), pp. 887-895.

Setia, P. and Patel, P.C., 2013, How information systems help create OM capabilities: Consequents and antecedents of operational absorptive capacity. Journal of Operations Management, 31 (6), pp. 409-431.

Shin, H., Lee, J-N., Kim, D. and Rhim, H., 2015. Strategic agility of Korean small and medium enterprises and its influence on operational and firm performance. International Journal of Production Economics, 168, pp. 181-196.

Tallon, P.P., 2011. Value chain linkages and the spillover effects of strategic information technology alignment: A processlevel view. Journal of Management Information Systems, 28(3), pp. 9-44.

Tallon, P.P. and Pinsonneault, A., 2011. Competing perspectives on the link between strategic information technology alignment and organizational agility: Insights from a mediation model. MIS Quarterly, 35(2), pp. 463-486.

Tan, C.S.L., Bi, R. and Smyrnios, K.X., 2014. The role of market orientation as a key factor in the development of supply chain capability in fast-growth family SMEs. Small Enterprise Research Journal, 21(1), pp. 14-32.

Teece, D., Peteraf, M. and Leih, S., 2016. Dynamic capabilities and organizational agility: Risk, uncertainty, and strategy in the innovation economy. California Management Review, 58 (4), pp. 13-35.

Teece, D.J., 2012. Dynamic capabilities: routines versus entrepreneurial action. Journal of Management Studies, 49 (8), pp. 1395-1401.

Terjesen, S., Patel, P.C. and Covin, J.G., 2011. Alliance diversity, environmental context and the value of manufacturing capabilities among new high technology ventures. Journal of Operations Management, 29(1-2), pp. 105-115.

Theyel, N., 2013. Extending open innovation throughout the value chain by small and medium-sized manufacturers. International Small Business Journal, 31(3), pp. 256-274.

Voss, G.B. and Voss, Z.G., 2013. Strategic ambidexterity in small and medium-sized enterprises: Implementing exploration and exploitation in product and market domains. Organization Science, 24(5), pp. 1459-1477.

Voss, U. and Brettel, M., 2014. The effectiveness of management control in small firms: Perspectives from resource dependence theory. Journal of Small Business Management, 52(3), pp. 569-587.

Wang, Y., Chen, Y. and Benitez-Amado, J., 2015. How information technology influences environmental performance: Empirical evidence from China. International Journal of Information Management, 35(2), pp. 160-170.

Weill, P., Subramani, M. and Broadbent, M., 2002. Building IT infrastructure for strategic agility. MIT Sloan Management Review, 44(1), pp. 57-66.

Whitten, G.D., Kenneth Jr, W.G. and Zelbst, P.J., 2012. Triple-A supply chain performance. International Journal of Operations and Production Management, 32(1), pp. 28-48.

Woldesenbet, K., Ram, M. and Jones, T., 2012. Supplying large firms: The role of entrepreneurial and dynamic capabilities in small businesses. International Small Business Journal, 30(5), pp. 493-512.

Wu, F., Yeniyurt, S., Kim, D. and Cavusgil, S.T., 2006. The impact of information technology on supply chain capabilities and firm performance: A resource-based view. Industrial Marketing Management, 35(4), pp. 493-504. 
Yang, J., 2014. Supply chain agility: Securing performance for Chinese manufacturers. International Journal of Production Economics, 150, pp. 104-113.

Yusuf, Y.Y., Gunasekaran, A., Musa, A., Dauda, M., El-Berishy, N.M., and Cang, S., 2014. A relational study of supply chain agility, competitiveness and business performance in the oil and gas industry. International Journal of Production Economics, 147, pp. 531-543.

Zhang, X., Donk, D.P.V. and Vaart, Tvd., 2016. The different impact of inter-organizational and intra-organizational ICT on supply chain performance. International Journal of Operations \& Production Management, 36(7), pp. 803-824.

\section{Appendix. Confirmatory Factor Analysis: Standardized Loadings and Reliability}

\begin{tabular}{|c|c|c|c|}
\hline Constructs & Indicators & $\begin{array}{l}\text { Standardized Factor } \\
\text { Loadings }\end{array}$ & $\begin{array}{l}\text { Indicator } \\
\text { Reliability }\end{array}$ \\
\hline \multirow[t]{4}{*}{$\begin{array}{l}\text { 1.IT-business } \\
\text { Alignment (ITAL) }\end{array}$} & $\begin{array}{l}\text { ITAL1: Our IT plan is strategically integrated with the } \\
\text { overall business plan. }\end{array}$ & .74 & .55 \\
\hline & $\begin{array}{l}\text { ITAL2: Our IT plan reflects our company's mission, goals, } \\
\text { objectives, and strategy. }\end{array}$ & .93 & .86 \\
\hline & $\begin{array}{l}\text { ITAL3: Our IT plan is based on a review of the business } \\
\text { plan and supports our business strategy. }\end{array}$ & .95 & .90 \\
\hline & $\begin{array}{l}\text { ITAL4: Our IT plan contains detailed action plans that } \\
\text { support our business strategy. }\end{array}$ & .71 & .50 \\
\hline \multirow[t]{3}{*}{$\begin{array}{l}\text { 2.Strategic } \\
\text { Collaboration (SCOL) }\end{array}$} & $\begin{array}{l}\text { SCOL1: Our company collaborates actively in forecasting } \\
\text { and planning with our business partners/suppliers. }\end{array}$ & .84 & .71 \\
\hline & $\begin{array}{l}\text { SCOL2: Our company develops strategic plans in } \\
\text { collaboration with our business partners/suppliers. }\end{array}$ & .92 & .85 \\
\hline & $\begin{array}{l}\text { SCOL3: Collaboration in demand forecasting and } \\
\text { planning with our business partners/suppliers is } \\
\text { something our company always does. }\end{array}$ & .93 & .87 \\
\hline \multirow[t]{3}{*}{$\begin{array}{l}\text { 3.Coordination } \\
\text { (COOR) }\end{array}$} & $\begin{array}{l}\text { COOR1: Our company conducts transaction follow-up } \\
\text { activities more efficiently with our business } \\
\text { partners/suppliers than do our competitors with theirs. }\end{array}$ & .79 & .62 \\
\hline & $\begin{array}{l}\text { COOR2: Our company spends less time on coordination } \\
\text { transactions with our business partners/suppliers than } \\
\text { our competitors with theirs. }\end{array}$ & .86 & .74 \\
\hline & $\begin{array}{l}\text { COOR3: Our company conducts the coordination } \\
\text { transactions at less cost than do our competitors with } \\
\text { theirs. }\end{array}$ & .90 & .81 \\
\hline \multirow[t]{3}{*}{$\begin{array}{l}\text { 4.Responsiveness } \\
\text { (RESP) }\end{array}$} & $\begin{array}{l}\text { RESP1: Compared to our competitors, our company } \\
\text { responds more quickly and effectively to changing } \\
\text { customer and supplier needs. }\end{array}$ & .73 & .53 \\
\hline & $\begin{array}{l}\text { RESP2: Compared to our competitors, our company } \\
\text { responds faster and more effectively to changing } \\
\text { competitor strategies. }\end{array}$ & .76 & .58 \\
\hline & $\begin{array}{l}\text { RESP3: Compared to our competitors, our company } \\
\text { develops and markets new products more quickly and } \\
\text { effectively. }\end{array}$ & .77 & .59 \\
\hline \multirow[t]{5}{*}{$\begin{array}{l}\text { 5.SME Performance } \\
\text { (SMEP) }\end{array}$} & $\begin{array}{l}\text { SMEP1: Compared to our competitors, our company } \\
\text { performs much better in growth in sales. }\end{array}$ & .76 & .58 \\
\hline & $\begin{array}{l}\text { SMEP2: Compared to our competitors, our company } \\
\text { performs much better in growth in profit. }\end{array}$ & .89 & .79 \\
\hline & $\begin{array}{l}\text { SMEP3: Compared to our competitors, our company } \\
\text { performs much better in growth in revenues. }\end{array}$ & .75 & .56 \\
\hline & $\begin{array}{l}\text { SMEP4: Compared to our competitors, our company } \\
\text { performs much better in new product development. }\end{array}$ & .71 & .51 \\
\hline & $\begin{array}{l}\text { SMEP5: Compared to our competitors, our company } \\
\text { performs much better in customer service. }\end{array}$ & .76 & .58 \\
\hline
\end{tabular}

Note. All factor loadings are significant at $p<0.001$ level 